\title{
Translating deictic motion verbs among Bulgarian, Croatian, and Serbian: A corpus-based study Svetlana NEDELCHEVA ${ }^{1}$ and Ljiljana ŠARIĆ ${ }^{2}$

\author{
${ }^{1}$ Shumen University \\ Shumen, Bulgaria \\ ${ }^{2}$ University of Oslo \\ Oslo, Norway
}

\begin{abstract}
This article deals with translating South Slavic deictic verbs. Specifically, we consider translations among Bulgarian, Croatian, and Serbian. Deictic verbs are verbs whose interpretation is dependent on the location of speech-act participants (Fillmore 1997), such as come and go. In research on Slavic, certain motion verbs' prefixes have been discussed as "deictic prefixes" (see Grenoble 1991, Filipović 2009, Łozińska 2018). Particular emphasis in this analysis is on the prefixed motion verbs dojda/doći, idvam/dolaziti, otida/otići, and otivam/odlaziti found in Bulgarian, Croatian, and Serbian literary texts and their translations. We present a brief quantitative overview and conduct a qualitative study of deixis-related meanings, paying necessary attention to other non-deictic meanings. Special attention is given to the constructional interplay of various deictic elements that co-occur with deictic verbs. Since we deal with literary texts and not everyday interaction, we consider the genre and context and apply the notion of viewpoint, which also covers the mental viewpoint adopted by the narrator, in addition to the "deictic" viewpoint of one of the speech participants. In the study, we observed shifts in point-of-view from deictic to non-deictic construal and vice versa, and from dynamic to static construal. These phenomena relate to the fact that in a text with a third person narrator, there is no innate deictic centre, while in casual conversation, the interlocutors create the deictic centre. The results show a preference for using come when motion towards a protagonist is described in a neutral context.
\end{abstract}

Keywords: Deixis, verbs of motion, corpus-based study, Bulgarian, Croatian, Serbian

\section{For citation:}

Nedelcheva, Svetlana \& Ljiljana Šarić. 2021. Translating deictic motion verbs among Bulgarian, Croatian, and Serbian: A corpus-based study. Russian Journal of Linguistics 25 (1). 43-67. DOI: 10.22363/2687-0088-2021-25-1-43-67 


\title{
Перевод дейктичекских глаголов движения между болгарским, хорватским и сербским языками: корпусное исследование
}

\author{
${ }^{1}$ Шуменский университет \\ Шумен, Болгария \\ 2 Университет Осло \\ Осло, Норвегия
}

Светлана НЕДЕЛЬЧЕВАํำ Ииляна ШАРИЧ²

\begin{abstract}
Аннотация
Статья посвящена переводу южнославянских дейктических глаголов между болгарским, хорватским и сербским языками. Дейктическими называются глаголы, интерпретация которых зависит от местонахождения участников речевого акта (Fillmore 1997), таких как соте (приходить) и go (уходить). В исследованиях славянских языков некоторые префиксы глаголов движения тракутуются как «дейктические префиксы» (см. Grenoble 1991, Filipović 2009, Łozińska 2018). Особое внимание в настоящем анализе уделяется префиксальным глаголам dojda/doći, idvam/dolaziti, otida/otići и otivam/odlaziti, обнаруживаемым в болгарских, хорватских и сербских литературных текстах и их преводах. Мы представляем краткий количественный обзор и проводим качественное исследование значений, связанных с дейксисом, уделяя необходимое внимание недейктическим значениям. Особый упор сделан на конструктивном вазимодействии дейктических элементов, сопутствующих дейктическим глаголам. Поскольку мы имеем дело с литературными текстами, а не бытовым взаимодействием, мы рассматриваем жанр и контекст и используем понятие «точка зрения», которое также включает ментальную точку зрения нарратора, в дополнение к «дейктической» точке зрения одного из участников речевого взаимодействия. В процессе исследования мы наблюдали переход точек зрения от дейктического к нейдектическому конструированию ситуации и наоборот, а также от динамического к статическому конструированию. Эти явления связаны с тем, что в повествовании от третьего лица отсутствует внутренний дейктический центр, в то время как в бытовых ситуациях дейктический центр создается собеседниками. Результаты исследования показывают, что предпочтение отдается глаголу приходить, когда в нейтральном контексте описывается движение по направлению к главному герою.
\end{abstract}

Ключевые слова: дейксис, глаголы движения, корпусное исследование, болгарский язык, хорватский язык, сербский язык

\section{Для цитирования:}

Nedelcheva S., Šarić L. Translating deictic motion verbs among Bulgarian, Croatian, and Serbian: A corpus-based study. Russian Journal of Linguistics. 2021. Vol. 25. № 1. P. 43-67. DOI: $10.22363 / 2687-0088-2021-25-1-43-67$

\section{Introduction}

Translating deixis can be a challenge for the translator. Various semantic and grammatical differences in language structure between the source language and the target language may cause difficulties in the translation process and lead to rendering an ambiguous target-language text. Correct deixis translation helps avoid misunderstanding on the part of the reader. The translator should accurately reveal the interlocutors' locations and how they move in space. We discuss prefixed 
motion verbs with deictic content and their translations following one of the main assumptions of cognitive linguistics: the understanding of such verbs requires extralinguistic knowledge.

Motion verbs serve as a point of access to speakers' encyclopedic knowledge. The encyclopedic view of meaning recognizes the essential role of both linguistic and extralinguistic contexts. Furthermore, the meaning of a linguistic unit depends on construal, which implies categorizing the same spatial situation in different ways that depend, on the one hand, on the speaker's world knowledge and specific viewpoint, and on the other, on the speaker's choices and the structure of the language used. The meaning dependent on construal implies not only some "objective" content but also how that content relates to the speaker. We will illustrate this with a few examples, considering deictic expressions in originals and literary translations from Croatian and Serbian to Bulgarian and from Bulgarian to Croatian. The differences between the source language and the target language may relate to the available set of deictic expressions (two-way deictic opposition versus three-way), ${ }^{1}$ and to specific choices made by the translators, who may adhere to the viewpoint conveyed in the original or choose another viewpoint, if the alternative solution seems equally logical in a given situation. Further, when confronted with similar languages, that is, translating from one Slavic language into another, translators can often choose a deictic prefixed verb very similar in form to the source expression as a translational equivalent. However, such choices may not be best because the meaning of verbs similar in form is not necessarily very close, and these may not be ideal translation equivalents, as we will show below. Translations may also avoid deictic information provided in the originals or may add deictic information. Further, deictic information conveyed by prefixed verbs can be strengthened by adding additional deictic information in translations.

\section{Theoretical background}

\subsection{Spatial deixis}

Deixis refers to "the location and identification of persons, objects, events, processes and activities being talked about, or referred to, their relation to the spatiotemporal context created and sustained by the act of utterance and the participation in it" (Lyons 1977: 637). It involves a (subjective) distinction between what is perceived as "proximal" to the deictic centre (DC) and what is perceived as "non-proximal" or "distal". Arguably, the most prototypical dimension of deixis is space deixis, which involves references to locations in terms of their perceived position in relation to the DC. Proximal deictic expressions such as here and this refer to locations that are perceived as close to the DC, and non-proximal

${ }^{1}$ Standard Bulgarian has a simplified two-way deictic opposition. The dialects of the central Rhodopes and transitional dialects of the extreme west of Bulgaria have three-way deictic systems in pronouns and articles. (Friedman 2006: 212). Croatian, as most of Bosnian/Croatian/Serbian, has a three-way deictic distinction. 
expressions such as that and there refer to locations that are perceived as far from that position. Space deixis includes the use of the motion verbs "come" and "go" to indicate, respectively, movement towards and away from the DC.

In a prototypical face-to-face communication, participants share the same fragment of reality and refer to it, that is, to the same place, which is "here" for both of them: the speaker is the determining factor, the centre on which the coordinate axes of time and space in the utterance are built. In this case, Bühler (1934) talks about deixis in sight and hearing, primary deixis, or deixis of the dialogue (e.g., Lyons 1977: 637-638; Nitsolova 1984: 71). In many other cases, such as, for example, in literary third-person narratives, in retelling, in giving instructions, and the like, deictic words represent a foreign (e.g., in a novel, a protagonist's) and not the speaker's (narrator's) point-of-view in spatial orientation. In this secondary spatial deixis, the DC is shifted to the protagonist's location or to a salient place.

\subsection{Deictic meaning of motion verbs. Deictic prefixes}

Prefixes such as $d o$ - 'to' and od-/ot- 'from' in Bulgarian and Croatian, which denote motion to and away from the speaker, respectively, belong to grammaticalized sets of deictic expressions (Łozińska 2018). To account for their deictic uses, analyzing the language alone is not sufficient; the interactional situation should also be considered-the time and place of their occurrence, the identities of the speaker and the listener, and the objects and events in the situational context (Lyons 1981: 170). A deictic expression includes reference to some ground element, and with this, a certain facet of the ground becomes objectified. The default senses of some verbs (e.g. English come and go, Bulgarian dojda and otida) are considered deictic because they presuppose a reference point equated with some element of the ground (Langacker 1987: 126-127). The deictic content in Slavic in descriptions of motion events is usually conveyed either by prefixes such as in (a) and (c), or by some other lexical units (e.g., adverbials in (b) and (d)):

1. (a) Otišao je u školu u osam. 'He went to school at 8 am.' (Cro.)

(b) Sjedio je $t u$ dva sata. 'He was sitting there for two hours.' (Cro.)

(c) Otide tam i sedna. '(He/she) went there and sat.' (Blg.)

(d) Često li idvaš́ $t u k$ ? 'Do (you) come here often?' (Blg.)

According to Fillmore (1971: 52), come "indicates the location of either the speaker or the listener at either coding time or reference time, or toward the location of the home base of either the speaker or the hearer at reference time". Similar phenomena can be illustrated by the use of Slavic deictic motion verbs - these usages are canonical because the speaker typically occupies the DC and adopts an egocentric worldview. ${ }^{3}$

${ }^{2}$ In Bulgarian, the equivalents of 'come' dojda-idvam are distinguished due to their aspect, i.e. the perfective verb dojda corresponds to the imperfective idvam.

${ }^{3}$ The usages of the English come in Come here! and Come here at dawn! provide the prototypical deictic sense of the English come (Radden 1996: 429). 
- The speaker's location at coding time

2. (a) Cro. Dođi odmah ovamo [čekam te]! 'Come here immediately (I am waiting)!'

(b) Blg. Idvaj ${ }^{4}$ tuk, čuvaš li? (BulNC) 'Come here! Do you hear me?'

- The speaker's location at reference time

3. (a) Dođi ovamo/ovdje kad ti bude teško... (hrWaC) 'Come here when you are in trouble.'

(b) Idvaj tuk, kogato imaš neprijatnosti. (BulNC) 'Come here when you are in trouble.'

These usages provide the prototypical deictic sense of the verbs dociidojda (idvam). The speaker may assume the listener's point-of-view at either coding or reference time, which is the case in $(4 a-b)$, with the assumption that the listener is at the square/school at the moment of speaking, or will be at the listener's home base $^{5}$ at the time agreed upon (4c) or appointed (4d):

4. (a) Cro. Doći ću tamo na plac. 'I will come (there) to the square.'

(b) Blg. Šte dojda v učilišteto. 'I'll come to the school.'

(c) Stoga nas pozovite... doći ćemo u dogovoreno vrijeme. (hrWaC) 'Call us... we will come at the agreed time.'

(d) Šte dojdem tam naj-mnogo do čas... (BulNC) 'We'll come there in no more than an hour.'

Some (prefixed) motion verbs describe a situation in which it is still possible to interact with the moving figure (the figure is accessible within the region of interactive focus (Lindner 1983)), whereas some others imply that the figure is beyond reach. The location of the viewpoint in a narrative/discourse may be inferred from the context and from the distribution of attention in the discourse.

In existing research on Slavic, the deictic content has been discussed in relation to the prefixes przy-/pri- and po- and to $w y-/ v y$ - and $w-/ v$ - in Polish and Russian (Łozińska 2018, Apresjan 1986, Grenoble 1998, Lewandowski 2014, von Waldenfels 2016). Lozińska (2018) claims that deictic motion away from or towards the speaker is typically coded by the Polish po- and przy- (although $w$ - and $w y$-also have deictic senses); przy- and pri- in Polish are primarily used to code the deictic relation of approaching the speaker or another DC, such as the place where the conceptualizer's attention is focused. South Slavic od-lot- and do- are comparable to po- and przy-: these prefixes code motion away from or towards the speaker.

The systemic relationships between the lexical meanings of Bulgarian motion verbs, as well as their use as deictic means of language, are studied by Trifonova

${ }^{4}$ The uses of $i d v a j$ ( 2 p. sg.) are not unambiguous-the movement may be directed both to the speaker's position at the moment of speaking and to his/her place at the moment of reference (Nicolova 1984: 78-79).

${ }^{5}$ Usages involving the home base result from the metonymic transfer from person to place. 
(1982), Nitsolova (1984), and Stanisheva (1985). Stanisheva claims that the verbs otivam/otida are used in cases when the speaker and the listener are in one place and "the movement is directed to another place" (Stanisheva 1985: 80). Following Fillmore's terminology (1983), Tchizmarova classifies the verbs as source-andpath oriented, path-and-goal oriented, path-oriented, goal-oriented, and sourceoriented. Her semantic analysis of seven motion verbs (otivam, idvam, hodja, vărvja, zaminavam, trăgvam, and pristigam) leads to the conclusion that each change-of-location verb "has its domain based on the meaning encoded in the verb and on the meaning of its modifiers, e.g., AdvPs and PPs" (Tchizmarova 2007: 144). They are rarely interchangeable and involve a shift of focus when one replaces another.

In the accounts of Cro. and Serb. verbs prefixed by od-/do-, scarce attention has been given to deictic information. Filipović's (2010) study shows that these verbs typically indicate movement "to or from the speaker or a scene", and the author claims that Serbian and Croatian have deixis as a strong feature of the system, which is reflected in the frequent use of $d o-/ o d-$ verbs. These verbs occur much more frequently than those having any other prefix in Serb./Cro. ${ }^{6}$ There is a preference for deictic $o d-/ d o$ - verbs in motion expressions, even when other prefixed verbs (e.g., iz-verbs) are possible. Otići and doći (both related to ići, 'go') are presumably the most frequent among these verbs because they are "generalized" motion verbs: in Cro./Serb. they can apply to different manners of motion, which can be expressed by another semantically much richer/more specific verb (e.g., doći teturajući versus doteturati 'come stumbling'). ${ }^{7}$

In the deictic uses of verbal prefixes, the type of construal of the profiled spatial relations is such that speakers are not explicitly profiled-what is profiled is their vantage point; their line of sight is evoked, and with this, they become "objectively construed" to some extent.

\section{Data and methodology}

In the following analysis, we provide a contrastive view of two verb pairs attested in a small collection of literary texts (six novels) translated from Croatian and Serbian into Bulgarian (three novels) and from Bulgarian into Croatian (three novels). Our choice of the texts for the small parallel corpus, which we compiled ourselves (see Table 1), was influenced by the availability of texts that (a) employ

\footnotetext{
${ }^{6}$ Filipović used the Croatian national corpus in her study.

${ }^{7}$ Cro. and Serb. dictionaries give hardly any information about the deictic information these verbs carry (e.g., there is no mention of speaker/hearer in the short definitions in HJP), contrary to Bulgarian dictionaries that provide this information (see BTR 1979 and RBE 1990). The deictic component in the meaning of $i d a 1 / i d v a m$ 'come' is pointed out in dictionary entries of the Bulgarian Interpretation Dictionary (1979) (BTR) and the Dictionary of Bulgarian Language (1990) (RBE). According to BTR, ida 1 'come' means "moving in the direction of the speaker or the person who is spoken to; I come", and according to RBE, idvam 'come' means " 1 . I move, usually to the place where the person who speaks is, I'm approaching, 2. I come to the place where the person who is talking is located."
} 
"modern language" and (b) entail a fair number of prefixed motion verbs that can be considered deictic in some of their usages.

We concentrate on two verb pairs in Croatian and Serbian and two corresponding verb pairs in Bulgarian, considering all the examples from the novels with the following verbs (all their morphological forms) meaning COME and GO: Bulgarian dojda (pf.) - idvam (ipf.); ${ }^{8}$ otida (pf.) - otivam (ipf.); Croatian and Serbian doći (pf.) - dolaziti (ipf.); otići (pf.) - odlaziti (ipf.).

Table 1

\section{Corpus of the study}

\begin{tabular}{|c|c|c|}
\hline Serbian and Croatian originals & Bulgarian translations & $\begin{array}{c}\text { Words } \\
\text { (originals) }\end{array}$ \\
\hline Andrić, Ivo: Na Drini ćuprija (Serb.), 1945. NDĆ & $\begin{array}{l}\text { Mostăt na Drina; transl. Lilija } \\
\text { Kackova (1964) }\end{array}$ & 115,423 \\
\hline $\begin{array}{l}\text { Pavić, Milorad: Hazarski rečnik. Roman-leksikon u } \\
100.000 \text { reči (Muški primerak) (Serb.) 1984. Haz }\end{array}$ & $\begin{array}{l}\text { Hazarski rečnik; transl. Hristijana } \\
\text { Vasileva (2005) } \\
\end{array}$ & 87,212 \\
\hline $\begin{array}{c}\text { Krleža, Miroslav: Povratak Filipa Latinovicza (Cro.) } \\
\text { 1932. PFL }\end{array}$ & $\begin{array}{l}\text { Zavrăštaneto na Filip Latinovič; } \\
\text { transl. Sijka Račeva (1966) }\end{array}$ & 66,073 \\
\hline Total Serb. and Cro. $\rightarrow$ Blg. & & 268,708 \\
\hline $\begin{array}{c}\text { Bulgarian originals } \\
\end{array}$ & Croatian translations $^{9}$ & Words \\
\hline Andreev, Emil. Stăklenata reka. Sofia, 2004. GIRiv & $\begin{array}{l}\text { Staklena Rijeka; transl. Ana } \\
\text { Vasung (2015) }\end{array}$ & 84,289 \\
\hline Karabashliev, Zakhari. 18\% sivo. Sofia, 2008. 18\%G & $\begin{array}{c}18 \% \text { sivo; transl. Ksenija Banović } \\
(2016)\end{array}$ & 74,758 \\
\hline Vulchanova, Ina. Ostrov Krah. Sofia, 2017. OKr & $\begin{array}{c}\text { Otok Krah; transl. Ksenija Banović } \\
\text { (2018) }\end{array}$ & 54,151 \\
\hline Total Blg. $\rightarrow$ Cro. & & 213,198 \\
\hline
\end{tabular}

In Bulgarian, dojda/idvam 'come', otida/otivam 'go' are in opposition to hodja 'go, walk' (indicating non-directed movement). Both idvam and otivam imply directed movement; the same goes for doci $i$ and otici $i$. In their turn, dojda/idvam 'come' and otida/otivam 'go' are in opposition by the feature "the place of the speaker and/or the listener" in their deictic usages. The same applies to oticii/odlaziti and doći/dolaziti. Cro. and Serb. hodati indicates non-directed movement, whereas $i c ́ i$ can refer to both directed and non-directed movement.

${ }^{8}$ The imperfective counterpart of Cro./Serb. doći is dolaziti. The exact Bulgarian equivalent of Cro./Serb. dolaziti and imperfective counterpart of dojda is dohoždam or dohaždam, which is not used in our corpus. Dohoždam/dohaždam are archaic and stylistically marked. Contemporary Bulgarian uses idvam in contexts in which the imperfective form of dojda is required; therefore, we treated idvam as the imperfective counterpart of dojda, as modern manuals do (https://rechnik.chitanka.info/). In fact, in our corpus, idvam is the most frequent translation of dolaziti.

${ }^{9}$ We are grateful to the publisher Hena.com and Nermina Husković, who provided searchable versions of the Croatian translations of the novels $18 \%$ sivo and Ostrov Krah, and to the translator of Stăklenata reka, Ana Vasung who provided the Croatian translation of the novel. Many thanks also go to Adriaan Barentsen who provided searchable versions of the novels Hazarski rečnik and Na Drini ćuprija and their Bulgarian translations. 
Verb frequency and translation equivalents

Table 2 provides an overview of the verbs examined in Serbian and Croatian novels and their translational equivalents. We identified the examples with "spatial" usages (potentially deictic) of the verbs in the originals. "Space" includes movement of abstract phenomena (e.g., temporal contexts with moving time).

Docildolaziti are in $61 \%$ and $66 \%$ of the examples translated with dojda/idvam, and in a considerable number of remaining cases with stigna 'arrive' and its prefixed forms. Nastăpi 'occur' and javi se 'appear' are also found repeatedly for doći. Dolaziti is often rendered (pri)stiga 'arrive'. The translation equivalents of such instances reveal that prefixed deictic verbs in the source language can be rendered by non-deictic verbs in the target language and vice versa; deictic verbs in translated texts can stand for non-deictic in the originals.

Table 2

Serb. and Cro. doći/dolaziti (pf./ipf.) and otići/odlaziti (pf./ipf.)

\begin{tabular}{|c|c|c|c|c|c|c|c|}
\hline $\begin{array}{c}\text { Serb. and } \\
\text { Cro. } \\
\text { novels }\end{array}$ & $\begin{array}{c}\text { No. of } \\
\text { ex. doći } \\
\text { (pf.) }\end{array}$ & $\begin{array}{l}\text { Transl. } \\
\text { doći }= \\
\text { dojda }\end{array}$ & $\begin{array}{c}\text { doći }= \\
\text { another } \\
\text { verb or } \\
\text { phrase* }\end{array}$ & $\begin{array}{c}\text { *doći }= \\
\text { (na-/pri- } \\
\text { do-stigna) }\end{array}$ & dolaziti & $\begin{array}{l}\text { dolaziti } \\
=\text { idvam }\end{array}$ & $\begin{array}{c}\text { dolaziti = } \\
\text { another } \\
\text { verb/ } \\
\text { phrase* }\end{array}$ \\
\hline $\begin{array}{c}\text { Na Drini } \\
\text { ćuprija } \\
\text { (Serb.) }\end{array}$ & $\begin{array}{l}120(91 \\
\text { space) }\end{array}$ & 82 & 38 & 19 & $80(54)$ & 55 & 25 \\
\hline $\begin{array}{c}\text { Hazarski } \\
\text { rečnik } \\
\text { (Serb.) }\end{array}$ & $97(71)$ & 55 & 42 & 20 & $53(37)$ & 34 & 19 \\
\hline \multirow{3}{*}{$\begin{array}{l}\text { Povratak } \\
\text { Filipa } \\
\text { Latinovicza } \\
\text { (Cro.) }\end{array}$} & $56(46)$ & 31 & 25 & 7 & $33(28)$ & 20 & 13 \\
\hline & & & & & & & \\
\hline & otići & $\begin{array}{l}\text { otići }= \\
\text { otida }\end{array}$ & $\begin{array}{c}\text { otići }= \\
\text { another } \\
\text { verb/ } \\
\text { phrase* }\end{array}$ & *of these & odlaziti & $\begin{array}{c}\text { odlaziti } \\
=\text { otivam }\end{array}$ & $\begin{array}{c}\text { odlaziti = } \\
\text { another } \\
\text { verb/ } \\
\text { phrase* }\end{array}$ \\
\hline $\begin{array}{l}\text { Na Drini } \\
\text { ćuprija }\end{array}$ & $43(39)$ & 26 & 17 & $\begin{array}{l}5 \text { trăgna/ } \\
\text { trăgvam } \\
5 \text { zamina/ } \\
\text { zaminavam }\end{array}$ & $37(36)$ & 23 & $\begin{array}{c}14 \\
6 \text { zamina/ } \\
\text { zaminavam }\end{array}$ \\
\hline $\begin{array}{c}\text { Hazarski } \\
\text { rečnik }\end{array}$ & 39 (37) & 29 & 10 & $\begin{array}{l}5 \text { trăgnal } \\
\text { trăgvam }\end{array}$ & 9 (9) & 4 & 2 hodja \\
\hline $\begin{array}{c}\text { Povratak } \\
\text { Filipa } \\
\text { Latinovicza }\end{array}$ & $6(6)$ & 5 & 1 & 1 dojda & $2(2)$ & 0 & $\begin{array}{c}2 \text { izljaza/ } \\
\text { izlizam }\end{array}$ \\
\hline
\end{tabular}

Otići/odlaziti are in $67 \%$ and $55 \%$ of the examples rendered otida/otivam. Frequent choices are also trăgna/trăgvam and zamina/zaminavam.

Table 3 presents the cases in which dojda/idvam 'come' and otida/otivam 'go' are used in Bulgarian translations as equivalents of verbs other than doći/dolaziti and oticilodlaziti. 
Come and go used in Blg. translations, not in the originals

\begin{tabular}{|c|c|c|c|c|}
\hline & dojda & idvam & otida (pf.) & otivam (ipf.) \\
\hline Na Drini ćuprija & 42 & 41 & 17 & 23 \\
\hline Hazarski rečnik & 18 & 5 & 8 & 11 \\
\hline Povratak Filipa Latinovicza & 9 & 6 & 23 & 13 \\
\hline
\end{tabular}

The most frequent Serb. verbs translated with the Blg. dojda (pf.) 'come' are stići 'arrive', naici i 'come', prići 'approach' and with the Blg. idvam (ipf.) 'come' - stizati 'approach', nailaziti 'come (across)'; stići 'arrive', naići, ići 'go', poći 'leave'. Other verbs used in Cro. (PFL) are pristupiti 'approach', doputovati 'arrive', pojaviti se 'appear', pokrenuti se 'move'. The Blg. idvam is frequently found in translating Cro./Serb. contexts employing static construals (biti 'be'). The most frequent verb translated with the Blg. otida/otivam 'go' is ići, followed by poći 'leave', prići 'approach', preći 'cross', krenuti 'set off', pristupiti 'approach', ući 'enter'. In similar cases, the Blg. translation adds deictic information not expressed in the originals or conveys deictic information expressed by other means in the original by using deictic verbs.

Table 4 provides an overview of verbs examined in Bulgarian novels and their translational equivalents.

Results for Blg. dojda/idvam (pf./ipf.), otida/otivam (pf./ipf.)

\begin{tabular}{|c|c|c|c|c|c|c|c|}
\hline $\begin{array}{c}\text { Bulgarian } \\
\text { novels }\end{array}$ & $\begin{array}{l}\text { No. of ex. } \\
\text { dojda (pf.) }\end{array}$ & $\begin{array}{c}\text { Transl. } \\
\text { dojda }= \\
\text { doći }\end{array}$ & $\begin{array}{c}\text { dojda }= \\
\text { another } \\
\text { verb or } \\
\text { phrase* }\end{array}$ & $\begin{array}{c}* \text { dojda }= \\
\text { (stići, } \\
\text { (pri)stići) }\end{array}$ & idvam & $\begin{array}{l}\text { idvam }= \\
\text { dolaziti }\end{array}$ & $\begin{array}{c}\text { idvam }= \\
\text { another } \\
\text { verb/ } \\
\text { phrase* }\end{array}$ \\
\hline $\begin{array}{l}\text { Stăklenata } \\
\text { reka }\end{array}$ & $\begin{array}{c}121 \\
\text { (98 space) }\end{array}$ & 98 & 23 & 6 & $\begin{array}{c}91 \\
\text { (68 space) }\end{array}$ & 75 & 16 \\
\hline $18 \%$ sivo & $\begin{array}{c}48 \\
\text { (27 space) }\end{array}$ & 32 & 16 & 5 & $\begin{array}{c}44 \\
\text { (26 space) }\end{array}$ & 36 & 8 \\
\hline \multirow[t]{2}{*}{ Ostrov Krah } & $\begin{array}{c}57 \\
\text { (45 space) }\end{array}$ & 50 & 7 & 3 & $\begin{array}{c}46 \\
\text { (21 space) }\end{array}$ & 37 & $\begin{array}{c}9 \\
2 \text { stići } \\
1 \text { prolaziti }\end{array}$ \\
\hline & otida & $\begin{array}{c}\text { otida }= \\
\text { otići }\end{array}$ & $\begin{array}{c}\text { otida }= \\
\text { another } \\
\text { verb or } \\
\text { phrase* }\end{array}$ & *of these & otivam & $\begin{array}{c}\text { otivam }= \\
\text { odlaziti }\end{array}$ & $\begin{array}{c}\text { otivam = } \\
\text { another } \\
\text { verb/ } \\
\text { phrase* }\end{array}$ \\
\hline $\begin{array}{c}\text { Stăklenata } \\
\text { reka }\end{array}$ & $\begin{array}{c}96 \\
\text { (85 space) }\end{array}$ & 81 & 15 & $\begin{array}{c}1 \text { stići } \\
1 \text { ići, } \\
1 \text { doći }\end{array}$ & $\begin{array}{c}24 \\
\text { (18 space) }\end{array}$ & 20 & $\begin{array}{c}4 \\
3 \text { ići }\end{array}$ \\
\hline $18 \%$ sivo & $\begin{array}{c}29 \\
\text { (27 space) }\end{array}$ & 20 & 9 & $\begin{array}{c}1 \text { zaputiti } \\
\text { se } \\
1 \text { doći }\end{array}$ & $\begin{array}{c}28 \\
\text { (25 space) }\end{array}$ & 18 & $\begin{array}{c}10 \\
2 \text { ići }\end{array}$ \\
\hline Ostrov Krah & $\begin{array}{c}38 \\
\text { (37 space) }\end{array}$ & 27 & 11 & $\begin{array}{c}2 \text { doći } \\
2 \text { završiti }\end{array}$ & $\begin{array}{c}33 \\
\text { (28 space) }\end{array}$ & 25 & $\begin{array}{c}8 \\
4 \text { ići }\end{array}$ \\
\hline
\end{tabular}


The Blg. dojda and idvam (see Table 4) are translated in $79 \%$ and $82 \%$ of the examples with doći/dolaziti. The dominant equivalents in the remaining cases are stići, (pri)stići 'arrive'. The Blg. dojda is also rendered pojaviti se, nastati 'appear'. ${ }^{10}$ Apart from dolaziti, idvam 'come' is often translated with ići and doći. When the meaning in Blg. is 'originate', in Serb./Cro. the translator chooses dolaziti, proizici i, or a verbless phrase. Spatial uses of otida/otivam 'go' outnumber considerably those of dojda/idvam 'come'. The Blg. otida/otivam 'go' are widely translated with otići/odlaziti 'go' (otida $\rightarrow$ otići 78\%; otivam $\rightarrow$ odlaziti 74\%), but we also found instances of doć $i$ 'come', ić $i$ 'go', and stić $i$ 'arrive'.

As can be seen in Table 5, Cro./Serb. translations use the equivalents of come and $g o$ when originals used some other verbs.

Table 5

Come and go in Cro./Serb. translations, not in the originals

\begin{tabular}{|c|c|c|c|c|}
\hline & doći & dolaziti & otići (pf.) & odlaziti (ipf.) \\
\hline Stăklenata reka & 27 & 7 & 43 & 12 \\
\hline 18\% sivo & 15 & 11 & 20 & 6 \\
\hline Ostrov Krah & 13 & 5 & 21 & 11 \\
\hline
\end{tabular}

The most frequent Blg. verbs rendered doći (pf.) 'come' are static constructions (Blg. săm 'be') and stana 'become', vljaza 'enter', stigam 'arrive', and rendered dolaziti (ipf.) 'come' - trăgvam 'set off', otpravjam se 'head for', hodja 'walk'. Blg. originals also used minavam 'pass', otdalečavam se 'walk away', and pristăpvam 'step to' when the translations chose doći/dolaziti. Otićilodlaziti 'go' are frequent translation equivalents of Blg. directed-motion verbs trăgvam 'set off' and zaminavam 'leave' but also the path-oriented vărvja 'go, walk' and hodja 'walk'. Other frequent verbs are izlizam 'go out', otpravjam se 'head for', and izbjagam 'run away'.

\section{Analysis}

Generally, in the case of motion away from the speaker, the source is the DC, and in the case of motion towards the speaker, the goal carries deictic information. Otići/otida 'go' lexicalizes movement away from the deictic source, whereas the conceptualizer's attention may follow the protagonist (and subsequent events take place at the goal of the movement), or the narrator's attention does not follow the central figure and subsequent events take place at the source of the movement. In addition to the deictic source, the prefix codes the initial part of the trajectory (but nevertheless, motion events described are usually goal-oriented). Profiling the initial part of the trajectory is a separate sense of the prefix that is devoid of deictic information. Motion away from the DC towards a known or unknown goal is lexicalized by means of od-/ot-; it designates motion out of the

${ }^{10}$ There are a number of instances of fixed, non-spatial expressions, such as dojde mu naum 'it came to his mind' - palo/padalo mu je na pamet. 
narrator's/conceptualizer's region of interactive focus. ${ }^{11}$ Deictic motion towards the "speaker" (narrator, character in the novel) is coded doći/dojda 'come' (but can also be coded pri-, or another prefix carrying deictic information).

\subsection{Similar construals in the originals and translations}

\subsubsection{Doći, dojda (pf.) - dolaziti, idvam (ipf.) 'come'}

The verbs imply movement 'to the reference point' in which the reference point refers to the speaker's (that is, character's or narrator's) position, or a scene-setting that is in the focus of the reader's attention-a position created by the narrative voice as the DC.

For example, in NDĆ, the general "spatial deictic centre" of the events (and readers' attention) is a small town, kasaba, and its surroundings (see 5). Another general and even broader "spatial deictic centre" is Bosnia. Many "comings" and "goings" in the novel relate to these locations:

5.
\begin{tabular}{|l|l|l|} 
Ima više od petnaest & Predi poveče ot & More than fifteen years \\
godina... doselio se $u$ & petnajset godini... v & ago ... a Mažar settled \\
kasabu neki Mađar sa & gradčeto se zaseli edin & in the hamlet with his \\
ženom... Odmah se & madžarin s žena si... & wife... It was \\
saznalo da su došli sa & Vednaga se razbra, če & immediately clear that \\
namerom da $u$ kasabi & sa došli $v$ gradčeto da & they had come to the \\
otvore radnju za koju u & otvorjat zavedenie, za & hamlet to open a place \\
narodu nije bilo imena. & koeto narodăt njamaše & for which the people \\
I otvorili su je tamo na & ime. I go otvoriha & had no name. And they \\
kraj varoši, ispod & nakraj grada, pod & opened it (there) in the \\
visokih topola koje & visokite topoli, koito & outskirts of town, under \\
rastu na podnožju & rastat v podnožieto na & the high poplars \\
Stražišta, u jednoj & Stražište, v edna stara & growing at the foot of \\
staroj begovskoj kući... & bejska kăšta... & Stražište, in an old bey \\
(NDĆ) & \multicolumn{2}{l|}{ house... } \\
\hline
\end{tabular}

The Bulgarian verb idvam 'come' marks a movement of the figure towards the location of the other participant in the conversation/situation, that is, a "movement towards a place which could be designated as here from the point-of-view of the speaker or hearer" (Trifonova 1982: 111, cf. Kostova 2004: 5-8). Despite the common collocation of idvam 'come' with the deictic adverb here, in (6) the reference place is marked with tam/tamo 'there' because the narrator is at a distance from it at coding time. The lead character, Marica, would not hypothetically move to the reference place, which is Victor's house. The use of idvam/dolaziti 'come' is motivated by the fact that both Victor and the narrative voice will be at the house at the reference time.

11 The deictic motion away from the speaker towards a known goal is most frequently performed by means of the prefix po- in both Polish and Russian (Kozińska 2018: 193). 


6.
\begin{tabular}{|l|l|l|}
\hline - Može da dojdete pri & Možete doći k meni & "You can come to my \\
mene - predloži Viktor. & - predložio je & place," Victor \\
$(\ldots)$ & Viktor... & suggested... \\
Šteše da sledi Viktor dali & Može pratiti Viktora & He would watch Victor \\
izliza noštem, a Marica & izlazi li noću, a & going out at night, and \\
ne bi idvala, kogato i toj & Marica neće dolaziti & Marica would not come \\
e tam. (GlRiv) & dok je on tamo. & when he was there. \\
\hline
\end{tabular}

The narrator's perspective on the scene is adopted both at coding and reference time. He is distal from the house at coding time but he will be proximal at reference time, when Marica would come. The Blg. conditional bi idvala 'would come' differs from the renarrative evidential form in aorist došli sa (in 5) because the former refers to a repetitive round trip, while the latter marks a single, onedirectional completed trip (Alexander 2000b: 14).

\subsubsection{Otići, otida (pf.) - odlaziti, otivam (ipf.) 'go'}

Otići, otida (pf.) - odlaziti, otivam (ipf.) 'go' are source- and path-oriented verbs that imply movement 'from the reference point': the reference point refers to the speaker's (that is, the character's/narrator's) position or scene-setting that is the focus of the listener's (that is, reader's) attention.

A significant difference between Cro./Serb. otići and Blg. otida 'go' pertains to the type of constructions in which the verbs appear. With otida (pf.)/otivam (ipf.), the goal or final destination is always specified, except in elliptical constructions in which the goal is mentioned in the broader context (Tchizmarova 2007: 124). A comparison between idvam 'come' and otivam 'go' shows that they share the sense of 'directedness' to an end point (Alexander 2000a: 106). With otići (pf.)/odlaziti (ipf.) 'go', the goal does not have to be specified (see below).

With oticilodlaziti, otida/otivam 'go' the motion event is conceptualized from the source-oriented perspective. Intrinsic features of their meaning are the movement away from the source and along a path. The third element of the movement - the goal — can be specified by an adverbial. In NDĆ, for instance, the narrator's voice usually centres the reader's attention in the small town, which is the general spatial DC, often referred to with here 'ovde', see (7). When the narrator chooses the perspective of departure, that perspective in many cases implies leaving the town. Note that the Blg. translation omits the first spatial adverb ovde 'here'.

\begin{tabular}{|c|c|c|}
\hline $\begin{array}{l}\text { Preko sto porodica } \\
\text { odlazi u Sarajevo, gde } \\
\text { ima izgleda da će biti } \\
\text { smešteni, a petnaestak } \\
\text { ostaje ovde u kasabi; to } \\
\text { su većinom oni koji } \\
\text { ovde imaju nekog } \\
\text { svoga. (NDĆ) }\end{array}$ & $\begin{array}{l}\text { Poveče ot sto semejstva } \\
\text { otivaha v Saraevo, } \\
\text { gdeto imalo izgledi da } \\
\text { bădat nastaneni, a } \\
\text { petnajsetina ostavaha } \\
\text { (...) v gradčeto; } \\
\text { povečeto ot tjah imaha } \\
\text { tuk po njakoj svoj. }\end{array}$ & $\begin{array}{l}\text { More than a hundred } \\
\text { families went to } \\
\text { Sarajevo, where they } \\
\text { were likely to be } \\
\text { accommodated, and } \\
\text { about fifteen remained } \\
\text { (here) in the hamlet; } \\
\text { most of them had } \\
\text { somebody here. }\end{array}$ \\
\hline
\end{tabular}


The adverbial, which introduces the goal of the movement, is realized by a PP (u/v Sarajevo).

In (8), the narrative focus of attention is first on the location called Mejdan, where the protagonist was located before leaving for the main sublocation of the narration (varoš) at the medial distance from the narrator's point-of-view (indicated by $t u$ ). Subsequently, the narrator leads the reader to a new location-kapija (also at the medial distance indicated by tamo). The focus shifts then on the protagonist's movement from the town (varoš) to a third new location. Otida can be used because the goal is specified:

\begin{tabular}{|c|c|c|}
\hline $\begin{array}{l}\text {... pa onda se } \\
\text { naljutio... i sišao s } \\
\text { Mejdana } u \text { varoš. } T u \\
\text { mu je neko kazao da } \\
\text { su ljudi sa detetom } n a \\
\text { kapiji. Otišao je tamo } \\
\text { da ih izgrdi... (NDĆ) }\end{array}$ & $\begin{array}{l}\text {... a posle se } \\
\text { razsărdil... i sljazăl ot } \\
\text { Mejdan } v \text { grada. Tuk } \\
\text { njakoj mu kazal, če } \\
\text { horata s deteto sa } n a \\
\text { kapijata. Otišăl tam da } \\
\text { gi nagălči... }\end{array}$ & $\begin{array}{l}\text {... and then he got } \\
\text { angry... and } \\
\text { descended from } \\
\text { Mejdan to the town. } \\
\text { Here someone told } \\
\text { him that the people } \\
\text { with the child were at } \\
\text { the gate. He went } \\
\text { there to scold them... }\end{array}$ \\
\hline
\end{tabular}

In (9), the morphologically closest deictic verbs are used (otida, otići). In the original, the narrator's voice presents the village as distal but in the second part of the sentence, the protagonist's perspective is adopted. The protagonist is already in the village at the reference time, which is signaled by tuk 'here'. In the translation, however, the narrator changes point-of-view and conceptualizes the village as distal (in relation to the DC "here"- the reference point the protagonist leaves) by using ondje. Note that Blg. does not have the three-way contrast as Serbian and Croatian do. The equivalent for both Cro./Serb. $t u$ (medial) and ondje (distal) is tam, and tuk is an equivalent for ovdje.

\begin{tabular}{|c|c|c|}
\hline $\begin{array}{l}\text {... toj otide v seloto na } \\
\text { žena si, za da oglavi } \\
\text { malkata cărkovna } \\
\text { obštnost s namerenie } \\
\text { da ostane tuk do kraja } \\
\text { na dnite si. (GlRiv) }\end{array}$ & $\begin{array}{l}\text {... on je otišao u selo } \\
\text { svoje žene kako bi } \\
\text { upravljao malom } \\
\text { crkvenom zajednicom } \\
\text { s namjerom da ondje } \\
\text { ostane do kraja svojih } \\
\text { dana. }\end{array}$ & $\begin{array}{l}\text {... he went to his } \\
\text { wife's village to head } \\
\text { the small church } \\
\text { community with the } \\
\text { intention of staying } \\
\text { here/ there for the end } \\
\text { of his days. }\end{array}$ \\
\hline
\end{tabular}

Depending on usage contexts of Blg. and Cro./Serb. od-/ot- in otići/otida 'go', the source-path-goal schema generates one of the following specific inferences (or their combination) attested in our material:

1) The figure has initiated motion from the deictic source and is still moving in the conceptualizer's region of interactive focus; see (10) in which imperfective verbs are used. This inference applies to both Serbian/Croatian and Bulgarian. 
10.

\begin{tabular}{|l|l|l|}
\hline ... no v săštija moment & U tom trenutku vidimo & ... but at the same time \\
viždame kak spira & automobil koji se & we see a car stop, \\
edna kola, ot neja & zaustavlja i iz kojeg & totally naked mom, \\
slizat čisto goli i & izlaze potpuno goli & dad, and three kids \\
mama, tatko i tri & mama, tata i troje & leave the car and go to \\
dečica i otivat da si & dječice i odlaze kupiti & buy tickets. \\
kupjat biletčeta. $(\mathrm{OKr})$ & ulaznice. & \\
\hline
\end{tabular}

Figure 1 illustrates movement away from the starting point up to a particular place on the path where the observer sees the figure going (represented by the black arrow). The observer is aware of the end-point of the movement although they may or may not see it. The dashed circle depicts the conceptualizer's region of interactive focus. At the time of speaking, the moving figure is within this area, thus motivating the choice of the imperfective form of the verb.

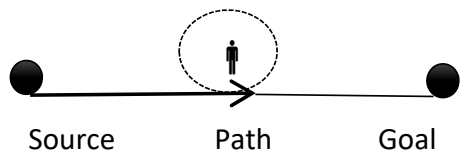

Figure 1. Imperfective otiva/odlaziti

(10) shows a close correlation between purposes and goals, corresponding to Lakoff et al.'s (1989) metaphor PURPOSEFUL ACTION IS DIRECTED MOTION TO A DESTINATION. Purposes have their deictic centre at the source but focus on the goal and have an ego moving, rather than the world, that is, a person deliberately acting upon the world, rather than having the world act upon the person (Radden 1988: 382 ).

2) The figure has initiated motion from the deictic source; in (11), the conceptualizer does not know whether the figure is still moving (the figure's trajectory disappears) - the moving figure has left the conceptualizer's region of interactive focus (see Figure 2).

This applies to otići/odlaziti 'go' in Croatian and Serbian and to Blg. Trăgna 'set off' in (11), but not to Blg. Otivam/otida 'go', which cannot be used when the goal or purpose is unspecified.

11.

\begin{tabular}{|c|c|c|}
\hline $\begin{array}{l}\text { I kako bi se kome } \\
\text { primakli, svaki je } \\
\text { napuštao položaj u } \\
\text { kome je dotada bio, } \\
\text { ostavljao sve i gledao } \\
\text { da što pre sakupi što je } \\
\text { njegovo i ode. (NDĆ) }\end{array}$ & $\begin{array}{l}\text { I štom se približeha do } \\
\text { njakogo, toj } \\
\text { promenjaše } \\
\text { položenieto, v koeto se } \\
\text { namiraše, ostavyaše } \\
\text { vsičko i gledaše } \\
\text { kolkoto može po-skoro } \\
\text { da săbere neštata si i } \\
\text { da si trăgne. }\end{array}$ & $\begin{array}{l}\text { And as they } \\
\text { approached someone, } \\
\text { they changed their } \\
\text { posture, left } \\
\text { everything, and tried } \\
\text { to quickly collect their } \\
\text { things and leave. }\end{array}$ \\
\hline
\end{tabular}


Figure 2 depicts the configuration of the Bulgarian source-oriented verb trăgna. It is similar to otida in that the starting point is encoded in its meaning, but it differs from it in its use without an explicitly specified goal. With trăgna, the goal is more often implied or irrelevant to the situation, illustrated by the transparent circle. The black arrow shows the movement of the figure already outside the area of the interactive focus of the observer.

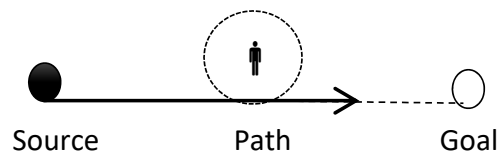

Figure 2. Perfective otići/trăgna

3) The figure has initiated motion from the deictic source and is no longer present there-the moving figure's absence is emphasized: see otici ' $g o$ ' in the Croatian translation in (12). In similar examples, Blg. uses the source-oriented zamina 'leave' that indicates movement away from the starting point. The reason for avoiding otida 'go' in this context is the absence of information about a specified goal or purpose:

12.

\begin{tabular}{|l|l|l|}
\hline $\begin{array}{l}\text { Kăde e prijatelkata ti? } \\
\text { - Zamina. (OKr) }\end{array}$ & $\begin{array}{l}\text { - Gdje ti je } \\
\text { prijateljica? } \\
\text { - Otišla je. }\end{array}$ & $\begin{array}{l}\text { - Where is your } \\
\text { friend? } \\
\text { - She left. }\end{array}$ \\
\hline
\end{tabular}

An illustration of this spatial configuration is the same as Figure 2. The choice of zamina instead of trăgna responds to the fact that the former "tends to be used with movements of longer duration and distances" (Tchizmarova 2007: 119); by contrast, the latter focuses on the time immediately preceding departure.

4) The conceptualizer's attention follows the figure's motion from the DC along the path to the goal of motion (the figure's activities at the goal are typically described). The use of $o d$-lot-involves a shift of DC that enables conceptualizing the events at the goal (see 13 and Figure 3):

13.

\begin{tabular}{|l|l|l|}
\hline Običaše da se & Volio je šetati gore po & He loved to walk up \\
razhožda iz gornata & brdu, oko Filipove & the hill, around \\
glama, okolo Filipova & rupe, rudnika bakra iz & Philip's hole-a mine \\
dupka - meden rudnik & rimskog doba, & from Roman times-a \\
ot rimsko vreme na & udaljena jedan & kilometer from the \\
kilometăr ot seloto. & kilometar od sela. & village. That summer, \\
$\begin{array}{l}\text { Onova ljato, sled } \\
\text { poroen dăžd, toj pak } \\
\text { be otišăl tam. (GlRiv) }\end{array}$ & $\begin{array}{l}\text { Onoga ljeta, nakon } \\
\text { obilne kiše, ponovno } \\
\text { je otišao tamo. }\end{array}$ & after a heavy rain, he \\
had gone there again.
\end{tabular}


In Figure 3, the eye symbolizes the conceptualizer, who is able to observe the movement of the figure from the source during the whole process of change of location until it reaches the goal. No region of interactive focus is marked because it covers the whole length of the path.

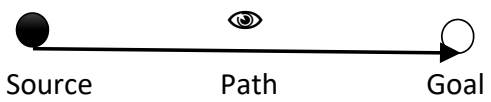

Figure 3. Perfective otida/otići

5) The speaker assumes that the protagonist's motion is intentional and goaldirected; even if the goal is not specified, constructions with such inferences can imply that the motion was goal-oriented and that the figure reached the goal. This applies to Serbian and Croatian otić ' 'go'. In these contexts, Blg. prefers the sourceoriented verbs zaminavam 'leave'/trăgvam 'set off' (see 14):

14.

\begin{tabular}{|l|l|l|}
\hline $\begin{array}{l}\text { I dali izobšto e kurort, } \\
\text { ili e zaminala } \\
\text { okončatelno? (OKr) }\end{array}$ & $\begin{array}{l}\text { I je li to uopće } \\
\text { ljetovanje ili je otišla } \\
\text { zauvijek? }\end{array}$ & $\begin{array}{l}\text { Is she at a resort, or } \\
\text { has she left/gone away } \\
\text { for good? }\end{array}$ \\
\hline
\end{tabular}

Although both zaminavam 'go, leave' and trăgvam 'go, leave' imply movement away from the source, they are not interchangeable. Trăgvam is commonly associated with everyday events - leaving for work/school, going to the shop or some kind of entertainement (theatre, movie, etc.) - whereas zaminavam refers to more singular occasions, such as going abroad, on a holiday, or on a business trip by means of a vehicle. The duration of the trip is also important: zaminavam and trăgvam indicate longer vs. shorter duration and distance, respectively.

\subsection{Different viewpoints in originals and translations}

In some narrative contexts, either verb pair (otićilotida, doći/dojda) is acceptable, but concrete choices relate to somewhat different construals in the originals as compared to translations. Sometimes, the originals use source-oriented verbs and translations are goal-oriented (and vice versa).

Otićilotida 'go' signals that the figure departed for a certain location, and doći/dojda 'come' signals that the figure arrived there. Thus, the same motion event can be encoded from either end of the spatial vector.

\subsubsection{Otida, otivam 'go' rendered doći/dolaziti 'come'}

If the narrative continues with the figure at location $\mathrm{X}$, it is not crucial to overtly mark the figure's arrival with the prefix do- (see the Blg. version in 15). The original in (15) focuses on the source of motion (the present location of the narrator/character). However, the Cro. translation focuses on the goal of motion by using doći, but also adds another deictic element, the medial adverb tamo 'there', 
before the adverbial na vratima pertaining to a part of the new location. With doci 'come', the narrative places the DC at the endpoint of the motion, whereas with otidoh 'go', the DC is at the previous source location:

15.

\begin{tabular}{|c|c|c|}
\hline $\begin{array}{l}\text { Obadih se po telefona } \\
\text { v pasportnata... Kato } \\
\text { otidoh, na vratata } \\
\text { pišeše: lična karta, } \\
\text { starija pasport i } \\
\text { aktualna snimka... } \\
(\mathrm{OKr})\end{array}$ & $\begin{array}{l}\text { Nazvala sam odjel za } \\
\text { putovnice... Kad sam } \\
\text { došla tamo, na } \\
\text { vratima je pisalo: } \\
\text { osobna karta, stara } \\
\text { putovnica i } \\
\text { fotografija. }\end{array}$ & $\begin{array}{l}\text { I called the passport } \\
\text { office... When I went } \\
\text { (there), I saw a sign on } \\
\text { the door that said: an } \\
\text { ID card, old passport, } \\
\text { and a photo... }\end{array}$ \\
\hline
\end{tabular}

According to Tchizmarova (2007: 132) otida and dojda are in complementary distribution: with the first verb, the goal location is usually a different place from that of the listener/speaker. By contrast, dojda is used when the goal of the figure is the speaker's/listener's location at "either coding time or reference time" (Fillmore 1971: 61). This substantial difference between otidoh and došla sam is eliminated in (15) by the change of perspective.

\subsubsection{Otići/odlaziti 'go' rendered dojda/idvam 'come'}

The opposite situation is illustrated in (16). In the Cro. original, the DC and the focus are at the source (the location of the protagonist who narrates the event, and another person), which the character should leave. In the Blg. translation, the focus is on the protagonist's goal, which is a third protagonist's location):

\begin{tabular}{|c|c|c|}
\hline $\begin{array}{l}\text { I onda me je poslala, } \\
\text { da odem do vas i da } \\
\text { vam kažem, da ona } \\
\text { ostaje, i da je njoj } \\
\text { dobro sa mnom! (PFL) }\end{array}$ & $\begin{array}{l}\text { I posle me izprati da } \\
\text { dojda do vas i da vi } \\
\text { kaža, če tja ostava i če } \\
\text { e dobre s men. }\end{array}$ & $\begin{array}{l}\text { And then she sent me } \\
\text { off to go/ to come to } \\
\text { your place and tell you } \\
\text { she was staying and } \\
\text { she was fine with me. }\end{array}$ \\
\hline
\end{tabular}

Similarly to (15), in (16) a different perspective is adopted in the original and the translation.

\subsubsection{Doći/dolaziti 'come' rendered otida, otivam 'go'}

17.

\begin{tabular}{|l|l|l|}
\hline Došao neko veče $u$ & Onaja večer otišăl $v$ & That night he \\
krčmu kod & krăcmata pri & came/went to \\
Siebenscheina i razbio & Zibenštajn i s butilka & Siebenschein's inn and \\
Štijefu Brezovečkom & sčupil glavata na Šefo & broke Štijef \\
flašom glavu, da mu & Brezovečki, za da mu & Brezovec's head with \\
dokaže da nije mrtav! & dokaže, če ne e & a bottle to prove he \\
$($ PFL $)$ & mărtăv. & was not dead. \\
\hline
\end{tabular}


In (17), the focus is on the goal (krčmu), and the DC is at that location in Cro., whereas Blg. adopts a different perspective; the movement is away from that place, which is the DC. In the Cro. original, the narrative conceptualizer is at the reference place when the figure arrives there. The evidential form of otida used in the Blg. translation suggests the narrative conceptualizer's absence at the reference place. We have no information about the location of the conceptualizer at the time the figure reaches the goal. The only fact we learn is that he/she is not a witness to the scene in the inn.

\subsubsection{Dojda/idvam 'come' rendered otići, odlaziti 'go'}

We found no instances of dojda 'come' translated with otići/odlaziti 'go'; however, in the corpus, the imperfective idvam had been rendered odlaziti (ipf.). See (18): in the original the narrator conceptualizes the monastery as a DC, the goaloriented idvam is used, and the figures move to the designated goal emphasized by the adverb tuk(a) 'here'. In the translation, the monastery is still the goal, but it is at a medial distance from the narrator's perspective (signalled by the adverb tamo), and the protagonists move away from the DC to the goal, which determines the use of the source-oriented odlazili 'go'.

18.

\begin{tabular}{|c|c|c|}
\hline $\begin{array}{l}\text { Văpreki, če živeeli v } \\
\text { săsedstvo s manastira, } \\
\text { Dimităr i Donato } \\
\text { nikoga ne bili idvali } \\
\text { tuka. (GlRiv) }\end{array}$ & $\begin{array}{l}\text { Iako su živjeli u } \\
\text { susjedstvu manastira, } \\
\text { Dimitar i Donato } \\
\text { nikada nisu tamo } \\
\text { odlazili. }\end{array}$ & $\begin{array}{l}\text { Although living near } \\
\text { the monastery, Dimitar } \\
\text { and Donato never } \\
\text { came here/ went } \\
\text { there. }\end{array}$ \\
\hline
\end{tabular}

\subsection{Focus on different portions of the path}

In some situations, when Blg. otida, otivam 'go' does not correspond to Cro./Serb. otici/odlaziti 'go' and vice versa, the originals and translations focus on different portions of the path.

For example, in (19), Blg. focuses on the movement away from the source and along a path, whereas Cro. concentrates on the smaller portion of the path by using the verb zaputiti se 'head for' with the ingressive meaning. The goal/end of the path is in the translation deictically designated by the added medial adverb tamo:

19.

\begin{tabular}{|l|l|l|}
\hline $\begin{array}{l}\text { Otidoh }(\ldots) \text { v edin } \\
\text { gorešt sledobed s } \\
\text { portfolioto si v răka. } \\
(18 \% \mathrm{G})\end{array}$ & $\begin{array}{l}\text { Zaputio sam se tamo } \\
\text { jednog vrućeg } \\
\text { popodneva s } \\
\text { portfoliom u ruci. }\end{array}$ & $\begin{array}{l}\text { I went } \text { (there }) \text { on a hot } \\
\text { afternoon with my } \\
\text { portfolio in hand. }\end{array}$ \\
\hline
\end{tabular}

In (20) (as in many other examples), the Blg. translation chooses the sourceoriented verb zamina 'leave' in the construction in which no goal is explicitly stated, just the fact that someone left. 


\section{0.}

\begin{tabular}{|l|l|l|}
\hline Prolazile su godine, & Minavaha godini, & Years passed, summers \\
smenjivala se leta i & smenjaha se leta i & and autumns, winters \\
jeseni, zime i proleća, & eseni, zimi i proleti, & and springs were \\
odlazili su i vraćali se & zaminavaha i se & passing by, workers and \\
radnici i majstori. & vrăštaha rabotnici i & $\begin{array}{l}\text { craftsmen were going } \\
\text { (NDĆ) }\end{array}$ \\
majstori. & and coming back. \\
\hline
\end{tabular}

Blg. often employs the source-oriented verbs denoting change of location zaminavam 'leave' or trăgvam 'set off', in contexts in which the goal is not the focus of attention, instead of otivam 'go', which requires an explicit goal. The starting point is not mentioned but it is implied in (20) in which the verb refers to all the workers and craftsmen associated with the DC.

There are contexts in which the Cro. original focuses on the path and the goal and uses doci 'come' to denote traversing the path and reaching the goal. As an equivalent, in such cases, Blg. translators sometimes use (pri)stigna 'arrive'. The verb focuses only on the goal, and its morphology encodes the meaning of goal, as the root stigam means 'to reach/arrive' and the prefix pri- means 'at' (Tchizmarova 2007: 138). If the change of location is according to a schedule, as in (21), the specific arrival time is also mentioned (at eight):

21.

\begin{tabular}{|c|c|c|}
\hline $\begin{array}{l}\text { Trafikantica Regina } \\
\text { došla je kući oko } \\
\text { osam, pogladila ga po } \\
\text { kosi i rekla mu neka } \\
\text { obuče svoje baršunasto } \\
\text { odijelo, jer da idu u } \\
\text { grad. (PFL) }\end{array}$ & $\begin{array}{l}\text { Lavkadžijkata Regina } \\
\text { pristigna } v \text { kăšti kăm } \\
\text { osem, pogali go po } \\
\text { kosata i mu kaza da si } \\
\text { obleče kadifenoto } \\
\text { kostjumče, zaštoto } \\
\text { šteli da otidat v grada. }\end{array}$ & $\begin{array}{l}\text { The shop assistant } \\
\text { Regina arrived home } \\
\text { at eight, stroked his } \\
\text { hair, and told him to } \\
\text { put on his velvet suit } \\
\text { because they would go } \\
\text { to town. }\end{array}$ \\
\hline
\end{tabular}

\subsection{A shift of viewpoint from deictic to non-deictic construal}

Occasionally, neither the original nor the translation uses verbs carrying explicit deictic information. Consider (22) in which the Cro. translation does not convey deictic information using the verb stići 'arrive', which designates simply reaching any goal no matter where the speaker/hearer is.

22.

\begin{tabular}{|l|l|l|}
\hline $\begin{array}{l}\text { Sled trideset minuti } \\
\text { rejsăt trjabvaše da } \\
\text { dojde. (GlRiv) }\end{array}$ & $\begin{array}{l}\text { Autobus treba stići za } \\
\text { trideset minuta. }\end{array}$ & $\begin{array}{l}\text { The bus had to come } \\
\text { in thirty minutes. }\end{array}$ \\
\hline
\end{tabular}

\subsection{A shift of viewpoint from dynamic to static construal}

In some situations, Blg. uses deictic construals involving movement of a figure toward a deictic centre, whereas in Cro. the figure is static and its presence at the reference place is emphasized, as in (23). The same applies to some Cro./Serb. 
examples with motion verbs that are translated with Blg. stative phrases emphasizing presence at a location.

23.

\begin{tabular}{|l|l|l|}
\hline $\begin{array}{l}\text { Povjarvajte mi, čela } \\
\text { săm dostatăčno, no } \\
\text { iskam da nauča ošte, } \\
\begin{array}{l}\text { zatova săm došla } t u k . \\
\text { (GlRiv) }\end{array}\end{array}$ & $\begin{array}{l}\text { Vjerujte da sam } \\
\text { dovoljno čitala, ali } \\
\text { želim još učiti i zato } \\
\text { sam } \text { ovdje. }\end{array}$ & $\begin{array}{l}\text { Believe me, I've read } \\
\text { enough, but I want to } \\
\text { learn more, so I } \\
\text { came/am here. }\end{array}$ \\
\hline
\end{tabular}

In (23), the original narration adopts the perspective of the protagonist. The figure moves to a goal, which is "here". In Cro., the activity is associated with neither movement nor change of place-rather it is a change of state.

\section{Key findings and conclusion}

This study revealed a general tendency for Cro./Serb. doći (pf.)/dolaziti (ipf.) 'come' to be translated with Blg. dojda (pf.)/idvam (ipf.) 'come' and vice versa, as initially expected and hypothesized. Cro./Serb. doći/dolaziti are in $61 \%$ and $66 \%$ of the examples in our data translated with Blg. dojda/idvam, and in a considerable number of examples with Blg. stigna 'arrive' and its prefixed forms. Blg. dojda and idvam 'come' are translated in $79 \%$ and $82 \%$ of the examples with Cro. doći/dolaziti 'come'. The dominant equivalents in the remaining cases are Cro. stići, (pri)stići 'arrive'. Additionally, Blg. dojda is also rendered Cro. pojaviti se, nastati 'appear', which are non-deictic and give evidence that prefixed deictic verbs in the source language can be translated with non-deictic verbs in the target language and that the target language can add deictic information. Bulgarian dojda/idvam 'come' and otida/otivam 'go' are used as equivalents of Cro. verbs other than doći/dolaziti. In similar cases, the Bulg. translations add deictic information. Also, Cro./Serb. translations add deictic information when using doći/dolaziti. Interestingly, doći/dolaziti are chosen much more often as translation equivalents of dojda/idvam than dojda/idvam are chosen to render doći/dolaziti (doći/dolaziti $\rightarrow$ dojdalidvam: 61\%, 66\%; dojda/idvam $\rightarrow$ doći/dolaziti: $79 \%, 82 \%$ ).

Blg. otida/otivam 'go' are widely translated with Cro. otići/odlaziti 'go' $(78 \%, 74 \%)$, but we also find some instances of $i c i$ ' $g o$ ' and stici 'arrive' as well as doć $i$ 'come' (indicating the opposite construal). Otić $i$ is more frequently rendered otida $(67 \%)$ than odlaziti with otivam $(55 \%)$, which suggests that the semantic differences between the imperfective verbs are greater than between perfective verbs.

In many situations, we found similar construals in the originals and translations: doci, dojda (pf.) was translated by dolaziti, idvam (ipf.) 'come' and otići, otida (pf.) with odlaziti, otivam (ipf.) 'go'. A significant difference between Cro./Serb. and Blg. pertains to the type of constructions in which the verbs otici $i$ and otida 'go' appear. With otida/otivam, the goal or final destination is almost always 
specified. For this reason, otići/odlaziti can be used in Cro./Serb. when the figure has initiated motion from the deictic source and the moving figure leaves the conceptualizer's region of interactive focus, whereas in such a situation without a specified goal or purpose, Blg. cannot use otivam/otida 'go', but instead uses the source-oriented verb trăgna. Cro./Serb. otići 'go' can be used when the moving figure's absence is emphasized - the figure has initiated motion from the deictic source and is no longer present there. In such situations, when the goal is not specified, Blg. prefers source-oriented verbs. In addition, when the speaker assumes that the protagonist's motion is intentional and goal-directed, even if the goal is not specified and the constructions imply that the motion is goal-oriented, Serb./Cro. uses otići 'go', whereas Blg. prefers source-oriented verbs.

A close examination of some of our examples revealed different viewpoints in the originals and the translations. In the source-target relation, shifts of viewpoint are observable-from deictic to non-deictic construal and vice versa. Further, the originals sometimes focus on the source of motion, whereas the translations focus on the goal (e.g., otida, otivam 'go' are rendered doći/dolaziti 'come'; docii/dolaziti 'come' are rendered otida, otivam 'go'; otići/odlaziti 'go' are rendered dojda/idvam 'come'), but both convey deictic information.

The originals and translations sometimes focus on different portions of the path. In these cases, Blg. otida, otivam 'go' is not translated with its closest Cro./Serb. (formal) equivalent otići/odlaziti 'go' but with, for example, zaputiti se 'head for', whereby the deictic information is lost in the target text. Blg. otivam requires an explicit goal, which is the reason that Blg. used, for example, zaminavam 'leave' for Cro. odlaziti, instead of otivam 'go' in some contexts, when the goal is not the focus. Finally, we also noticed a shift of viewpoint from dynamic to static construal and vice versa, in some examples in which doći/dolaziti 'come', otići/odlaziti 'go', dojda/idvam 'come', and otida, otivam 'go' are rendered as a stative verb in the target language.

In narrative texts such as those in our collection, the narrators present events from different viewpoints. Usually, it is the viewpoint of a protagonist, and the narrator identifies with that viewpoint or a narrator's viewpoint. We also observed shifts in point-of-view stemming from the fact that in a third-person narrative, there is no inherent deictic centre, while in spontaneous conversation, the participants create the deictic centre, and here deixis plays a role in the distribution of prefixes such as $d o^{-}, o t-, o d-$, pri-, and so forth. In the translations of the narrative texts under consideration, we found shifts in point-of-view from deictic to non-deictic construal and vice versa, and from dynamic to static construal and vice versa.

When motion towards a protagonist (their location) is described in a neutral context, the use of come is preferred: since the protagonist is at the goal of motion, it is natural for them to take their own arrival-oriented perspective. The goal of motion can be constituted by the listener, in which case the arrival-oriented perspective can also be taken. The departure perspective can be due to the sourcepath expression "from there", which determines the spatial orientation of the utterance. 
When narrators/protagonists talk about places they did not go and use expressions of the type "come (there)", the goal of movement has already been introduced in the discourse, and it serves as a focal ground of the narration in the universe created by the narrator.

The observations made in this study can help translators avoid misunderstandings related to transferring deictic situations from the source language to the target language. Translating deixis can be a challenge for translators due to subtle differences in language structures (e.g., the inventory of motion verbs and subtle differences in the meanings of verbs similar in form) and can lead to an ambiguous translation. This research used deictic verbs as examples in only three South Slavic languages, but it revealed some general principles of perceiving participants' locations and movement in space in literary discourse.

(C) Svetlana Nedelcheva and Ljiljana Šarić, 2021 @creative

This work is licensed under a Creative Commons Attribution 4.0 International License https://creativecommons.org/licenses/by/4.0/

\section{REFERENCES}

Alexander, Ronelle. 2000a. Intensive Bulgarian: A Textbook and Reference Grammar, Volume 1. Madison, WI: University of Wisconsin Press.

Apresyan, Yuri. D. 1986. Deixis in vocabulary and grammar and the naive model of the world. Semiotics and Informatics 28. Moscow [Dejksis v leksike i grammatike i naivnaja model' mira. Semiotika i informatika. 28, 5-33. Moscow].

Bühler, Karl. 1934. Sprachtheorie: Die Darstellungsfunktion der Sprache. Jena: Fischer.

Filipović, Luna. 2009. Intratypological Contrasts: Serbian and English through a Cognitive Linguistics Prism. Slavic Cognitive Linguistics Conference of the Slavic Cognitive Linguistics Association, 15-17 October 2009, Prague. URL: http://old.ucjtk.ff.cuni.cz/ sclc/SCLC09abstracts.pdf.

Filipović, Luna. 2010. The importance of being a prefix. Victoria Hasko, Renee Perelmutter (eds.). New Approaches to Slavic Verbs of Motion, 247-266. Amsterdam: John Benjamins.

Fillmore, Charles J. 1971. Coming and going. Santa Cruz Lectures on Deixis. Berkeley: University of California. 50-69.

Fillmore, Charles J. 1983. How to know whether you are coming or going. Gisa Rauth (ed.). Essays on Deixis. Tubingen: Gunter Narr Verlag, 219-27.

Fillmore, Charles J. 1997. Lectures on Deixis. Stanford, CA: CSLI Publications.

Grenoble, Lenore A. 1991. Deixis, point of view, and the prefixes po- and pri- in Russian. Die Welt der Slaven 36(1). 254-270.

Grenoble, Lenore A. 1998. Deixis and information packaging in Russian discourse. Pragmatics \& Beyond, 50. Amsterdam: John Benjamins Press.

Kostova, Nadezhda. 2004. Verbs of movement with deictic meaning. BAS Conference, 2004. Sofia: BAS, 1-8. [Glagoli za dviženie s deictični značenija. Konferencija na BAN, 2004. Sofia: BAN, 1-8 (In Bulg.)]. 
Lakoff, George, Esperson, Jane, Goldberg, Adele. 1989. Master Metaphor List. First Edition. URL: http://cogsci.berkeley.edu/pub/cogling/Metaphor.

Langacker, Ronald. 1987. Fondations of Cognitive Grammar I. Theoretical Prerequisitions. Stanford: Stanford University Press.

Lewandowski, Wojciech. 2014. Deictic verbs: Typology, thinking for speaking and SLA. SKY Journal of Linguistics 27. 43-65.

Lindner, Susan. 1983. A Lexico-Semantic Analysis of English Verb Particle Constructions with Out and Up. Bloomington: Indiana University Linguistics Club.

Łozińska, Joanna. 2018. Path and Manner Saliency in Polish in Contrast with Russian: A Cognitive Linguistic Study. Leiden and Boston: Brill.

Lyons, John. 1977. Semantics Vols. 1 and 2. London: Cambridge University Press.

Lyons, John. 1981. Language, Meaning and Context. Glasgow: Fontana/Collins.

Nitsolova, Rumyana. 1984. The Pragmatic Aspect of the Sentence in Standard Bulgarian. Sofia. [Pragmatičen aspekt na izrečenieto v bălgarskija knižoven ezik. Sofia. (In Bulg.)].

Radden, Günter. 1988. The concept of motion. In Understanding the Lexicon: Meaning, Sense and World Knowledge in Lexical Semantics, eds. W. Hullen and R. Schulze, 380-394. Tübingen: Niemeyer.

Radden, Günter. 1996. Motion metaphorized: The case of 'coming' and 'going'. Eugene Casad (ed.), Cognitive Linguistics in the Redwoods: The Expansion of a New Paradigm in Linguistics, 423-458. Berlin, New York: Mouton de Gruyter.

Šarić, Ljiljana and Tchizmarova, Ivelina. 2013. Space and metaphor in verbs prefixed with od-/ot- 'from' in Bosnian/Croatian/Serbian and Bulgarian. Oslo Studies in Language 5(1), 7-33.

Semino, Elena. 2011. Deixis and fictional minds. Style 45 (3). 418-440. URL: https://www.academia.edu/553190/Semino_E._2011_Deixis_and_fictional_minds_Style 45 3 418-40.

Stanisheva, Dina. 1985. The use of verbs of movement in Bulgarian taking into account the addressee's perspective. [Upotreblenie glagolov dviženija $\mathrm{s}$ učetom faktora adresata $\mathrm{v}$ bolgarskom jazyke. (In Russ)] Zeitschrift für Slawistik 30. 78-84. Akademie Verlag.

Tchizmarova, Ivelina. 2007. Bulgarian verbs of change of location. Journal of Slavic Linguistics. 15(1). 109-148.

Trifonova, Yordanka. 1982. On the opposition ida/hodja in contemporary Bulgarian. Language and Literature, 4. [Za opozicijata ida/hodja v săvremennija bălgarski ezik. Ezik $i$ literatura, 4 (In Bulg.)].

von Waldenfels, Ruprecht. 2016. Easy come, easy go: Balkan Slavic motion verbs from a parallel corpus perspective. International Conference on Corpus-Based Approaches to the Balkan Languages and Dialects, 5-7 December 2016, Saint Petersburg. URL: https://iling.spb.ru/confs/balkan2016/slides/waldenfels.pdf.

\section{Dictionaries and textbooks}

Alexander, Ronelle. 2000b. Intensive Bulgarian: A Textbook and Reference Grammar, Vol. 2. Madison, WI: University of Wisconsin Press.

BTR. 1979. Bulgarian Language Dictionary. Sofia, 1979. [Bălgarski tălkoven rečnik. Sofia, 1979. (In Bulg.)].

RBE. 1977-2015. Dictionary of the Bulgarian Language. BAS, 1977-2015. [Rečnik na bălgarskija ezik. BAS, 1977-2015. (In Bulg.)]. URL: http://ibl.bas.bg/rbe/

\section{Article history:}

Received: 21 July 2020

Accepted: 22 January 2021 


\section{История статьи:}

Дата поступления в редакцию: 21 июля 2020

Дата принятия к печати: 22 января 2021

\section{Bionotes:}

Svetlana NEDELCHEVA has a PhD in English Linguistics and is currently an Associate Professor of English at Konstantin Preslavsky University of Shumen. She is the author of two monographs Cognitive interpretation of the English preposition ON and Space, Time and Human Experience: A Cognitive View on English and Bulgarian Prepositions. Her research interests are in the field of cognitive semantics, conceptual metaphor, corpus linguistics, contrastive analysis of languages, translation studies and foreign language teaching.

\section{Contact information:}

Shumen University

115, Universitetska str., Shumen, 9700

e-mail: s.nedelcheva@shu.bg

ORCID: 0000-0003-1614-8758

Ljiljana ŠARIĆ is Professor of South Slavic linguistics at the University of Oslo. Her current research focus is on space in language, conceptual metaphor, metaphor and emotions, and figurative language in various discourse genres. She has authored and coauthored numerous books and articles dealing with semantics, cognitive linguistics and discourse analysis. Recent publications include Metaphor, Nation and Discourse (Benjamins, 2019) and Slike jezika: temeljne kognitivnolingvističke teme (Key Topics in Cognitive Linguistics) (Jesenski \& Turk, 2019).

\section{Contact information:}

ILOS, University of Oslo

Boks 1003 Blindern, 0315 Oslo, Norway

e-mail: 1jiljana.saric@ilos.uio.no

ORCID: 0000-0003-4373-9182

\section{Сведения об авторах:}

Светлана НЕДЕЛЬЧЕВА - имеет степень $\mathrm{PhD}$, доцент Шуменского университета им. Константина Преславского. Она является автором двух монографий - Cognitive interpretation of the English preposition ON («Когнитивная интерпретация английского предлога ON») и Space, Time and Human Experience: A Cognitive View on English and Bulgarian Prepositions («Пространство, время и человеческий опыт: когнитивный взгляд на английские и болгарские предлоги»). Сфера ее научных интересов включает когнитивную семантику, концептуальную метафору, корпусную лингвистику, контрастивный анализ языков, переводоведение и преподавание иностранных языков.

\section{Контактная информация:}

Shumen University

9700 Shumen, Bulgaria

e-mail: s.nedelcheva@shu.bg

ORCID: 0000-0003-1614-8758 
Лиляна ШАРИЧ - профессор, преподает южнославянскую лингвистику в Университете Осло. В настоящее время занимается пространственностью в языке, концептуальной метафорой, связью метафоры с эмоциями и образным языком в различных дискурсивных жанрах. Является автором и соавтором многочисленных книг и статей, посвященных семантике, когнитивной лингвистике и дискурс-анализу. Ее новейшие публикации - Metaphor, Nation and Discourse («Метафора, нация и дискурс») (Benjamins, 2019) и Slike jezika: temeljne kognitivnolingvističke teme («Ключевые темы в когнитивной лингвистике») (Jesenski \& Turk, 2019).

\section{Контактная информация:}

ILOS, University of Oslo

Boks 1003 Blindern, 0315 Oslo, Norway

e-mail: ljiljana.saric@ilos.uio.no

ORCID: 0000-0003-4373-9182 